\title{
Infeksjonsrisiko under anti-TNF-behandling
}

\author{
Bruk av tumornekrosefaktor- $\alpha$ - \\ hemmere ved inflammatorisk \\ tarmsykdom gir forbigående økt \\ risiko for alvorlig infeksjon de \\ første tre månedene
}

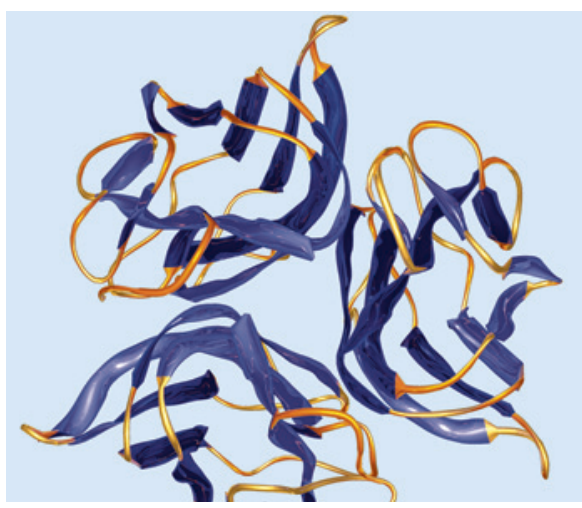

Illustrasjonsfoto: Science Photo Library
Tumornekrosefaktor- $\alpha$ (TNF- $\alpha$ )-hemmere er effektive i behandlingen av en rekke immunmedierte sykdommer, men kan også føre til alvorlige bivirkninger. I en registerbasert kohortstudie av pasienter med inflammatorisk tarmsykdom ble risiko for alvorlig infeksjon etter behandling med TNF- $\alpha$-hemmere undersøkt (1).

Innen 90 dager etter behandlingsstart hadde 51 av 1543 pasienter behandlet med TNF- $\alpha$-hemmere fått infeksjon, mot 33 av 1543 ubehandlede pasienter (hasardratio 1,$63 ; 95 \%$ KI 1,01-2,63). I løpet av det første året var hasardratio 1,27 (95\% KI $0,92-1,75)$. For flere organspesifikke infeksjoner var hasardratio $>2$, men det var statistisk signifikans kun for hud- og bløtdelsinfeksjoner (hasardratio 2,51).

Dette er en viktig studie som viser behovet for observasjonsstudier som supplement til randomiserte placebokontrollerte studier, sier avdelingsoverlege Tom Christian Martinsen ved Avdeling for fordøyelses- og leversyk- dommer, St. Olavs hospital. I nesten alle randomiserte kontrollerte studier av anti-TNFbehandling ved inflammatorisk tarmsykdom konkluderer man med at det ikke er forskjell i risiko for infeksjoner mellom behandlingsgruppen og placebogruppen. Imidlertid erfarer alle som har drevet med slik behandling over tid at dette ikke er tilfellet. Pasientene som inkluderes i randomiserte kontrollerte studier er selekterte og representerer kun i begrenset grad de pasientene vi har i daglig klinisk praksis, sier Martinsen.

\section{Trine B. Haugen}

Tidsskriftet

\section{Litteratur}

1. Nyboe Andersen N. Pasternak B. Friis-Møller N et al. Association between tumour necrosis factor$\alpha$ inhibitors and risk of serious infections in people with inflammatory bowel disease: nationwide Danish cohort study. BMJ 2015; 350: h2809.

\section{Transfusjon og koagulopati ved alvorlig traume}

\begin{abstract}
Blødning er en vanlig dødsårsak etter traumer. Transfusjonsbehandling med en høy andel plasma og blodplater har imidlertid begrenset effekt på traumeindusert koagulopati.
\end{abstract}

Alvorlig blødning etter traumer behandles med hemostatisk resuscitering, der erytrocyttransfusjon suppleres med en høy andel plasma og blodplater. Studier har vist at slik blodkomponentbehandling gir bedret overlevelse, men forskere mener nå at det i disse studiene har vært seleksjonsskjevhet.

I tidsskriftet Intensive Care Medicine er det nylig publisert en prospektiv kohortstudie, der målet var å undersøke om et slikt transfusjonsregime kan korrigere traumeindusert koagulopati (1). Av 106 traumepasienter med blødning som ble inkludert, hadde over $40 \%$ koagulopati ved innkomst.

Denne andelen steg til $81 \%$ etter transfusjon av åtte enheter med erytrocytter. Alle koagulasjonsparametere ble forverret under blødning. Transfusjon med høy andel plasma viste ingen klar fordel. Kun en kombinasjonsbehandling med høydose plasma, kryopresipitat og blodplater samt et høyt fibrinogennivå syntes å bedre koagulasjonen.

- Studien tyder på at hemostatisk resuscitering ikke bedrer traumeindusert koagulopati under pågående blødning, sier Corinna Maintz, som er seksjonsoverlege på Anestesi- avdelingen, Sykehuset Østfold og medlem av traumeutvalget.

- Dette er interessante og litt uventede funn. Men studien besvarer ikke andre viktige spørsmål: Hvor mye verre hadde koagulopatien blitt uten tilførsel av koagulasjonsfaktorer? Hvilken klinisk effekt har det at koagulasjonen ikke normaliseres? Ville behandling med traneksamsyre ha gjort en forskjell? Kanskje man ender opp med transfusjonsprotokoller som er enda mer aggressivt rettet mot korreksjon av koagulopati, der man ikke «tynner ut» koagulasjonsfaktorene med erytrocyttkonsentrat? Her er det grunnlag for oppfølgingsstudier, mener Maintz.

\section{Liv-Ellen Vangsnes}

Tidsskriftet

\footnotetext{
Litteratur

1. Khan S, Davenport R, Raza I et al. Damage control resuscitation using blood component therapy in standard doses has a limited effect on coagulopathy during trauma hemorrhage. Intensive Care Med 2015; 41: 239-47.
}

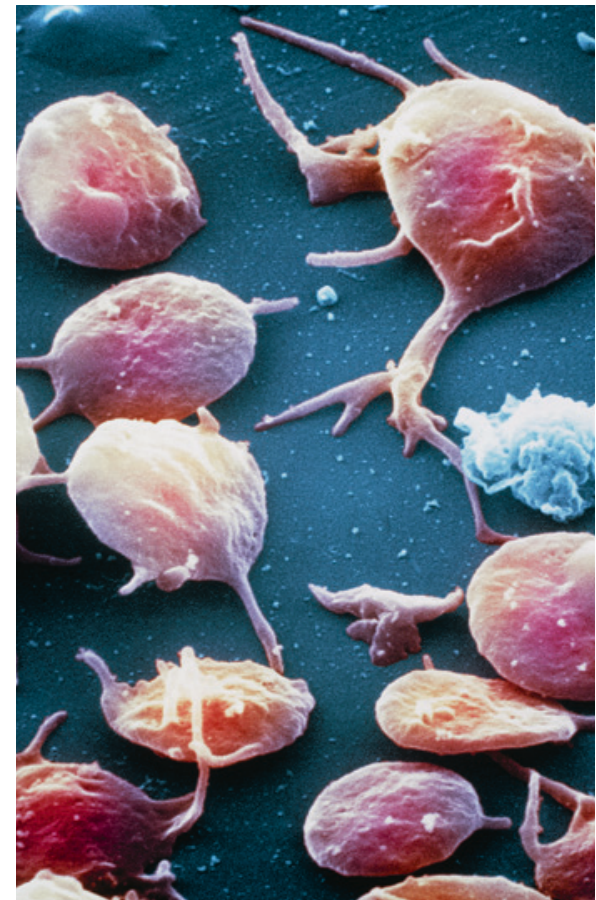

Illustrasjonsfoto: Science Photo Library 